$1-1-1955$

\title{
Nutritional status studies in Monongalia County, West Virginia
}

Faith Wolfe Chalmer

Follow this and additional works at: https://researchrepository.wvu.edu/ wv_agricultural_and_forestry_experiment_station_bulletins

\section{Digital Commons Citation}

Chalmer, Faith Wolfe, "Nutritional status studies in Monongalia County, West Virginia" (1955). West Virginia Agricultural and Forestry Experiment Station Bulletins. 375T.

https://researchrepository.wvu.edu/wv_agricultural_and_forestry_experiment_station_bulletins/632 @ WVU. It has been accepted for inclusion in West Virginia Agricultural and Forestry Experiment Station Bulletins by an authorized administrator of The Research Repository @WVU. For more information, please contact ian.harmon@mail.wvu.edu. 


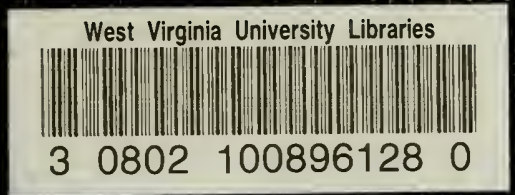


Digitized by the Internet Archive in 2010 with funding from

Lyrasis Members and Sloan Foundation 
June 1955

NUTRITIONAL STATUS STUDIES

In Monongalia County, West Virginia 


\section{AUTHORS}

Authors of Nutritional Status Studies in Monongalia County, West Virginia,* are Faith Wolfe Chalmers, Assistant Nutritionist, Division of Home Economics; L. Louise Chapman, Assistant Agricultural Biochemist; John J. Lawless, Director, University Health Service, and Associate Professor of Medicine; Walter R. Lewis, Agricultural Biochemist and Head of Agricultural Biochemistry; Sam Stregevsky, formerly Assistant Agricultural Biochemist; Orville L. Voth, Assistant Agricultural Biochemist; and A. H. VanLandingham, formerly Head of Agricultural Biochemistry, and now Assistant Dean and Assistant Director.

*Supported in part by funds from Regional Projects NE-4 ("Nutritional Status Studies") and NE-16 (Relationship of Nutrient Intake to Nutritional Status in Human Subjects"), cooperative studies involving Agricultural Experiment Stations in the Northeast Region.

WEST VIRGINIA UNIVERSITY

Agricultural. Experiment Station

College of Agriculture, Forestry, and Home Economics

H. R. VARney, Diregtor

MORGANTOWN 


\section{Summary and Conclusions}

In 1950-52, studies were made of 430 third and fourth grade school children in Monongalia County, West Virginia, to obtain information concerning dietary intake, blood levels of various nutrients, and the incidence of certain physical signs thought to be associated with malnutrition. These studies indicated that children living in small mining communities had poorer diets and lower blood levels than those living in urban areas.

These nutritional status studies were extended in 1952 to include 462 grade school and junior high school children from four mining communities in Monongalia County. In 1953, studies also were made on 57 adults and 137 children from 39 families living in mining areas. These studies included only microchemical blood tests and medical inspections. Although no diet studies were made, there were indications that the inadequate diets observed for the school children were common to other family members.

Dietary information for the school children was obtained from seven consecutive 24-hour recalls of all food eaten. This information indicated that calcium, phosphorus, ascorbic acid, and riboflavin were the nutrients most frequently needed in larger amounts. The microchemical analyses also indicated a need for more ascorbic acid and vitamin $\mathrm{A}$ in the diets of many children in all age groups.

Physical inspections of the subjects in this study revealed more signs of deficiencies generally related to poor diets than were observed in similar subjects in Maine and New York. However, most of the signs noted were given a low intensity rating. A number of children had mild cases of gingivitis and cheilesis, which are sometimes attributed to deficiencies of riboflavin, niacin, iron, and ascorbic acid. Some children also exhibited slight enlargement of the thyroid gland. Often this is caused by a lack of iodine. These physical symptoms are important since they may be indicative of inadequate nutrition over long periods.

Most diets could have been improved to meet the Recommended Dietary Allowances of the National Research Council by the addition of more milk, citrus fruits, green and yellow vegetables, and whole grain cereals. The use of iodized salt also should be encouraged in this area. 


\section{Contents}

SUMMARY AND CONCLUSIONS $\ldots \ldots \ldots \ldots \ldots \ldots \ldots \ldots \ldots$

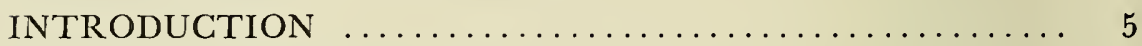

REVIEW OF LITERATURE $\ldots \ldots \ldots \ldots \ldots \ldots \ldots \ldots \ldots \ldots$

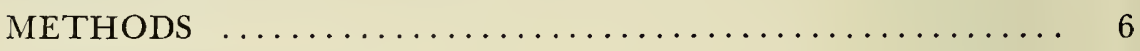

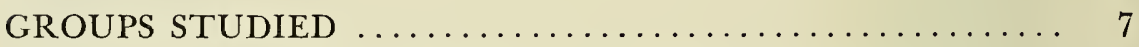

Third and Fourth Grade School Children in Monongalia COUNTY

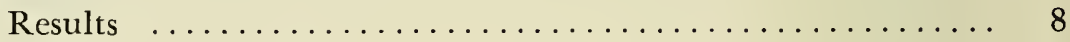

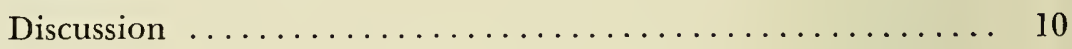

Summary $\ldots \ldots \ldots \ldots \ldots \ldots \ldots \ldots \ldots \ldots \ldots \ldots \ldots \ldots \ldots \ldots \ldots \ldots, 11$

Grade School and Junior High School Children from Four Mining Communities

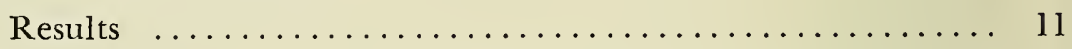

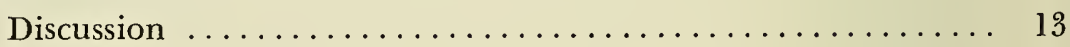

Summary $\ldots \ldots \ldots \ldots \ldots \ldots \ldots \ldots \ldots \ldots \ldots \ldots \ldots \ldots \ldots \ldots \ldots \ldots \ldots$

Mining Families in Monongalia County

Results ............................. 16

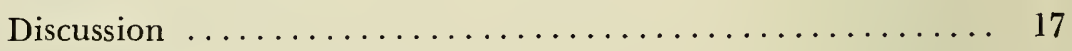

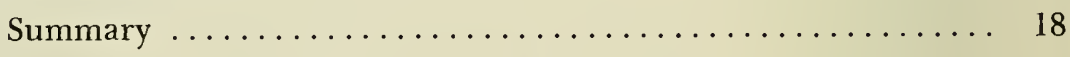

GENERAL DISCUSSION OF RESULTS $\ldots \ldots \ldots \ldots \ldots \ldots \ldots, 18$

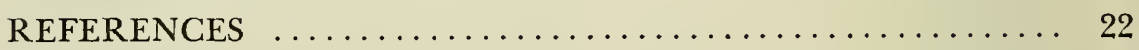

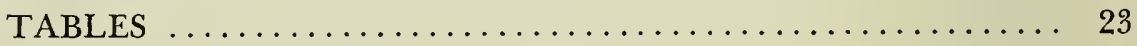




\section{Nutritional Status Studies in Monongalia County, West Virginia}

Introduction

Although much information has been published concerning the nutritional status of various population groups in the United States, few studies have been made of the nutrition of persons living in mining areas.

In West Virginia many small mining towns or "mining camps" still exist. Since bituminous coal mining is one of the largest industries in the State and since so many coal miners live in these small communities, the nutritional well-being of this population group is important to the State as a whole.

To obtain specific information about the food habits and nutritional status of groups in a given area, nutrition surveys must be made. In West Virginia, such studies have been chiefly confined to school children because information regarding the nutritional status of this age group is of great importance in evaluating and improving the nutrition of a population.

During three school years (1950-53), studies were made of 892 grade school and junior high school students and 39 mining families in Monongalia County, West Virginia. Dietary studies, microchemical blood analyses, and medical inspections to detect certain physical signs associated with malnutrition were conducted by members of the Department of Agricultural Biochemistry, the Division of Home Economics, and the University Health Service of West Virginia University.

\section{Review of Literature}

At other agricultural experiment stations in the Northeast Region, children from 4 to 15 years of age have been studied as part of the NE-4 cooperative project for evaluating the nutritional status $(1,2,3,4)$. Nutrient intakes of vitamin $\mathrm{A}$, calcium, riboflavin, and ascorbic acid were lower, in relation to the Recommended Dietary Allowances of the National Research Council, than those of other nutrients (2). Low blood levels for ascorbic acid, carotene, and vitamin A also were reported for children in this age group (3). Clinical signs possibly related to nutritional deficiencies were detected in all population groups studied (4). 
In Vermont, the nutritional status of 386 children was studied by medical examinations and one-day diet records (5). Blood analyses for ascorbic acid were made for about 175 subjects. These studies indicated the need for more fresh fruits and vegetables, particularly those rich in ascorbic acid.

Similar nutrition studies conducted in Pennsylvania compared the nutritional status of 147 children living in a college community with that of 428 school children from a small industrial city $(6,7)$. There were indications that the children from the college community were in better nutritional condition. Even in this community, however, some children were not optimally nourished. General over-all consumption of milk and fruits was higher in the college community.

In West Virginia, a brief study of the dietary habits of 1,200 school children has been conducted (8). One-day food records collected at that time indicated that, in general, diets were low in citrus fruits, green and yellow vegetables, milk, and milk products.

In Maine, where seven-day dietary records were collected three times a year from children above the third grade, the diets tended to be low in calcium, thiamine, riboflavin, niacin, and ascorbic acid (9).

When the diets of 350 New York state school children from 4 to 18 years of age were studied in the fall and the spring of the same year, it appeared that the younger children met the NRC Recommended Allowances more frequently than the older children (10). Calcium and ascorbic acid were the nutrients most often lacking in the diets of the older children.

In Connecticut, dietary records from 385 children in the fourth to the eighth grades were checked for the basic food groups (11). The greatest deficiencies in intakes were found in green and yellow vegetables, citrus fruits, milk, and whole grain cereals.

\section{Methods}

Plan of Study

During the school years of 1950-52, dietary studies, medical inspections, and blood serum analyses were made for 430 third and fourth grade school children from 19 elementary schools in Monongalia County. Since these data indicated poorer dietary patterns and lower blood values for children from mining areas, similar studies were conducted in 1925-53 for 462 grade school and junior high school students in four mining communities. In addition, during the summer of 1953, microchemical blood analyses and medical inspections were made of the parents and children in 39 mining families. 


\section{Dietary STUdies}

Individual nutrient intakes were determined by seven consecutive 24-hour dietary recalls. Although seven-day diet records are more commonly used in this type of study, the authors believed that, for school children, more reliable information could be obtained by the recall method. Each child was interviewed daily by a trained interviewer who recorded the kinds and amounts of foods eaten during the previous 24-hour period. Various sizes of glasses, cups, and bowls were used to help estimate sizes of food portions. The total food intake was recorded in household measurements.

All records were calculated in terms of average daily intakes of calories, protein, calcium, phosphorus, iron, thiamine, riboflavin, niacin, and ascorbic acid. In 1950-52, the U.S. Public Health Service Food Value Tables were used for these calculations (12). In 1952-53, the Food Tables of the Bureau of Human Nutrition and Home Economics were used (13). In all cases, a simplified method of dietary calculation developed by Dr. M. J. Babcock (14) was followed. Since recent researci has indicated that vitamin A cannot be determined accurately from dietary records (15), values for vitamin A were not calculated.

\section{BLood STUdies}

At the end of the seven-day period of dietary study, non-fasting blood samples were obtained by finger puncture. The microchemical methods used for determining hemoglobin, ascorbic acid, vitamin $\mathrm{A}$, and carotene were slight modifications of those developed by $\mathrm{O}$. A. Bessey and $\mathrm{O} . \mathrm{H}$. Lowry and associates and have been described previously (1).

\section{Medical Inspections}

The subjects in this study were given medical inspections to detect possible signs of nutritional deficiencies. All were examined by the same physician, who had special training in recognizing certain conditions often associated with poor nutrition (4).

\section{Groups Studied}

Details of the studies made with each of the three population groups are given in the following three sections. The methods used in all three studies were those described above.

\section{THIRD AND FOURTH GRADE SCHOOL CHILDREN IN MONONGAL!A COUNTY}

During the school years of 1950-51, and 1951-52 a study was made of 430 third and fourth grade school children in Monongalia County, West Virginia, to obtain information concerning dietary intake, blood levels of various nutrients, and the incidence of certain physical signs 
associated with malnutrition. The study included 216 boys and 214 girls from 19 elementary schools. The ages of the students ranged from 7 to 12. Forty-six per cent were living in urban areas, 44 per cent in small industrial or mining communities, and 10 per cent in rural areas. The results of the dietary studies, microchemical blood analyses, and physical inspections were compared for the children from these different types of communities. Since such a small percentage were living in rural or farming areas, data for this group have been omitted from this report.

\section{RESULTS}

\section{DieTARY INTAKes}

The data from the dietary studies were evaluated in terms of the Recommended Daily Dietary Allowances set up by the Food and Nutrition Board of the National Research Council (1). Table 1 shows the percentages of school children whose diets met or exceeded the recommended amounts and the percentages with diets furnishing less than the recommendations.

Sixty-four per cent of the children were consuming diets which met or exceeded the NRC recommendations for protein intake, whereas only 4 per cent were getting less than two-thirds of this amount.

The intakes of calcium, phosphorus, and iron were frequently lower than the NRC recommended allowances. Only about one-half and onethird of the subjects obtained the full amounts recommended for calcium and phosphorus, respectively. Nineteen per cent failed to obtain even two-thirds of the desirable amount of phosphorus.

Thiamine, riboflavin, and niacin were frequently consumed in somewhat less than desirable amounts, but intakes seldom fell below two-thirds of the NRC recommendations.

Many diets were low in ascorbic acid. Almost 20 per cent of the subjects obtained less than half, and another 16 per cent obtained less than two-thirds of the recommended allowance.

\section{BLOOD LeVELS}

Each student was rated as "poor," "fair," "good," or "excellent" for hemoglobin, ascorbic acid, vitamin A, and carotene, according to the amounts present in the blood. The rating system used was that proposed by O. A. Bessey and O. H. Lowry (17) and is reproduced in Table 2. A summary of the results of the blood analyses is given in Table 3.

Fifty-nine per cent of the students were rated as "fair" for the percentage of hemoglobin in their blood. Twenty-eight per cent of the 
boys and girls were in the "good" range, and only 10 per cent were rated as "excellent." On the other hand, less than 4 per cent were classified as "poor" for hemoglobin concentrations.

Almost 25 per cent of the boys and girls ranked in the "poor" group for vitamin A levels. Only 4 per cent fell in the "excellent" range, although 32 per cent were rated as "good."

For carotenes, which are broken down in the body to form vitamin A, approximately 17 per cent of the boys and girls were rated as "poor." Less than 3 per cent of the children ranked as "excellent," but 32 per cent were rated as "good." Forty-eight per cent were rated only as "fair" for carotene.

Ratings for ascorbic acid were somewhat higher than those for vitamin A and carotene. Sixty-two per cent of the children fell in the "good" or "excellent" range. Almost 30 per cent, however, were rated "fair," and 9 per cent were ranked in the "poor" group.

\section{MEDicAl INSPECTIONS}

The percentage of boys and girls who showed physical abnormalities possibly related to poor nutrition is given in Table 4 .

Some signs possibly related to vitamin A deficiency were noted. About 6 per cent of the children had inflamed eyelids (blepharitis) which may have been caused by a lack of vitamin A or riboflavin $(18,19)$. Thickening of the bulbar conjunctiva was present in about 2 per cent of the children examined. In addition, folliculosis (skin that is dry and rounghened by many pinhead size bumps) was noted for 4 per cent of the boys and girls. This skin disorder also may have been caused by a lack of vitamin A $(18,19)$.

Lesions of the outer canthi, sometimes attributed to a need for riboflavin, were noted for 5 per cent of the children. Sixteen per cent also had reddened, peeling lips (cheilosis), sometimes caused by a deficiency of riboflavin, niacin, or iron $(18,19)$. Changes in the tongue papillae were observed in less than 2 per cent of the boys and girls.

It should be noted that 12 per cent of the children examined had slight enlargements of the thyroid gland. This may have been caused by a deficiency of iodine.

About 4 per cent of the children showed an increase in vascularity of the bulbar conjunctiva which might have been caused by a deficiency of ascorbic acid (20). In addition, almost 20 per cent had inflammed gums (gingivitis), often attributed to a lack of ascorbic acid $(18,19,20)$.

\section{Nutritional Status in Urban and Industrial Areas}

The percentages of children from urban and industrial areas whose diets met or exceeded the NRC Recommended Daily Dietary Allowances 
are shown in Table 5. Since more of the industrial than the urban group was studied in the fall and early winter months, comparisons of the two groups should be made with some reservations. With this in mind, it may be noted that the data indicate a smaller proportion of the industrial than of the urban group received the recommended allowance of nutrients. It is the opinion of the authors that had all subjects been studied in the spring, the differences would have been greater.

The results of the blood analyses for children from urban and industrial areas are shown in Table 6. For all the analyses except hemoglobin, more children from urban areas were rated as "good" or "excellent" than were those from industrial areas.

Table 4 compares the frequency with which physical signs possibly related to poor nutrition were observed for the children from these two types of communities. Eye abnormalities were noted more frequently in the industrial areas, whereas cheilosis was reported more frequently in the urban areas.

It should be noted that the children living in mining or industrial communities had poorer diets and lower blood values than those who lived in urban areas. These differences might have been even more pronounced were it not for the school lunch programs in the mining communities. School lunches were served in all except one of these schools, whereas only one of the urban schools had a lunch program.

\section{Nutritional Status in Rural Areas}

There also were indications that the children living on farms or in rural areas had poorer diets and lower blood values than those living in urban areas. However, only 10 per cent of all the children studied lived in such communities. Consequently, no valid conclusions can be drawn except that a more extensive study of this group may be warranted.

\section{DISCUSSION}

From the results of the dietary studies, it may be noted that calcium, phosphorus, and ascorbic acid were the nutrients most frequently needed in larger amounts. Microchemical blood analyses also indicated a need for more ascorbic acid in the diet, as well as a need for more vitamin A. Certain physical signs which may have been associated with a deficiency of ascorbic acid, riboflavin, or iodine were noted.

Although only a small percentage of the children examined showed physical signs which may have been caused by poor nutrition, one should remember that dietary deficiencies may exist for long periods before any physical signs of nutritional deficiencies appear.

In general, the diets of the children from small industrial or mining communities were poorer than those of the boys and girls living in 
urban areas. The children from mining communities also had lower blood rating than did those from urban areas, although schools in the mining communities had school lunch programs.

It is recommended that more milk, green and yellow vegetables, and citrus fruits be included in the diets of these children. The use of iodized salt might also be stressed as a preventive of simple goiter, since 12 per cent of the children examined showed some enlargement of the thyroid gland.

\section{SUMMARY}

A survey of the nutritional status of 430 third and fourth grade school children from Monongalia County, West Virginia, was conducted at West Virginia University during the school years of 1950-51 and 1951-52. Results of the dietary studies, microchemical blood analyses, and medical inspections indicated that the diets of these children, particularly those living in small mining or industrial communities, were deficient in calcium, phosphorus, vitamin $\mathrm{A}$, and ascorbic acid.

\section{GRADE SCHOOL AND JUNIOR HIGH SCHOOL CHILDREN FROM FOUR MINING COMMUNITIES}

The nutritional studies of third and fourth grade school children, reported in the preceding section of this bulletin, indicated that children from several small mining communities were in poorer nutritional condition than were those from urban areas. Since little information is available concerning the nutritional status of persons living in mining communities and since such information is needed as a basis for a wellrounded program in nutrition for West Virginia, 462 grade school and junior high school students from four small mining communities in Monongalia County were included in similar nutrition studies during the school year of 1952-53.

Children from the second through the ninth grades participated in this nutritional survey. Their ages ranged from 7 to 15 years. Dietary information was obtained from 111 boys and 130 girls. Blood samples were collected from 232 boys and 230 girls and medical inspections of 224 boys and 221 girls were made to detect signs of possible nutritional deficiencies. Table 7 shows the number of children studied at each school.

\section{RESULTS}

\section{DieTARy INTAKes}

Dietary studies were made in only two schools. These data are presented in Table 8 in terms of the NRC Recommended Dietary Allowances. 
The protein and calcium intakes of roughly one-third of the children in the 10-15-year age groups were less than 66.6 per cent of the NRC recommendations. The intake of the 7-9-year age group was distinctly better than those of the older groups for these two nutrients.

The phosphorus intake of the various age groups followed a pattern similar to that for protein and calcium. A large part of the subjects ingested less than 66.6 per cent of the recommended allowance and the intake of the 7-9-year group was better than that of other groups.

Many of the older children failed to get the amount of iron recommended by the NRC. Only 14 per cent and 42 per cent of the children in the 13-15- and 10-12-year groups respectively were getting the full amount recommended.

The average daily intakes of thiamine, riboflavin, and niacin were relatively high for the younger children, but an appreciable portion of the older groups needed to increase their intake of these vitamins.

A large portion of the subjects in all age groups failed to obtain adequate amounts of ascorbic acid. Among the children over 10 years of age, more than one-third of the group failed to get 50 per cent, and an additional one-fifth failed to get 66.6 per cent of the NRC recommended allowance.

\section{BLOOD LEVELS}

Table 9 shows the distribution of subjects according to ratings of blood constituent levels. These data have been interpreted in terms of the rating scale proposed by $O$. A. Bessey and O. H. Lowry (17), which has been duplicated in Table 2 .

Hemoglobin levels were rated as good or excellent for more than half of the children in each age group. A large portion (44 per cent) in the 7-9-year group received a "fair" rating, but very few children of any age group were found in the "poor" group.

Blood levels for ascorbic acid tended to be low as might be expected on the basis of the low dietary intakes reported in the previous section. About half of the children in each age group were rated either "poor" or "fair."

Blood serum vitamin A and carotene levels also tended to be low. Almost two-thirds of the children received ratings of "poor" or "fair" for vitamin A, and only about 10 per cent received an "excellent" rating. Carotene ratings showed a similar distribution.

\section{Medical InSPECTIONS}

When the children were examined for physical signs of nutritional deficiencies, a number of abnormalities were noted which might have 
been caused by poor nutrition. Table 10 shows the types of abnormalities detected and the percentage of children exhibiting such defects.

Certain eye abnormalities were noted at the different schools. Between 9 and 12 per cent of the children showed blepharitis, which is sometimes related to a deficiency of riboflavin or vitamin A $(18,19)$. Increased vascularity of the conjunctiva was noted for less than 3 per cent of the children between the ages of 7 and 12 and for none of the older students.

Several skin conditions also were noted. Mild nasolabial seborrhea, sometimes attributed to deficiencies of riboflavin $(18,19)$, vitamin $A$, or ascorbic acid (20), was seen in about 6 per cent of the children from 10 to 12 years of age. In the 13- to 15-year age group, approximately 28 per cent of the boys and girls had nasolabial seborrhea. When the skin of the upper arms was examined, less than 2 per cent of the children had dry scaly skin (xerosis) and 4 to 11 per cent had dry, goose-pimply skin (folliculosis). Both of these skin conditions may be related to a need for more vitamin A $(18,19)$.

A larger percentage of the children showed certain changes in the lips and gums. Mild cases of cheilosis were exhibited by 43 per cent of the 7- to 12-year-old children and by 41 per cent of the boys and 16 per cent of the girls in the 13- to 15-year age group. Cheilosis is sometimes attributed to a deficiency of riboflavin, niacin, or iron $(18,19)$.

Mild to moderate cases of gingivitis were noted for all age groups and might have been caused by a deficiency of ascorbic acid $(18,19,20)$. About 30 per cent of the 7-to 9-year-old children and 35 per cent of the 10- to 12-year-old children showed gingivitis. In the 13- to 15-year age group, 53 per cent of the boys and 34 per cent of the girls exhibited similar gum conditions. Changes in the papillae of the tongue, sometimes attributed to a deficiency of riboflavin or niacin $(18,19)$, were noted for less than 5 per cent of all the children examined.

Slight enlargement of the thyroid gland was noted for all age groups. Seven per cent of the 7- to 9-year-old children showed such enlargement. In the 10- to 12-year age group, 11 per cent of the boys and girls showed signs of goiter, and 2 per cent of the boys and 13 per cent of the girls between the ages of 13 and 15 had gland enlargement. Since such enlargement often may be caused by a deficiency of iodine, the need for more wide-spread use of iodized salt seems obvious.

\section{DISCUSSION OF RESULTS}

From the data furnished by the microchemical blood analyses, there were indications that more foods rich in ascorbic acid, vitamin $\mathrm{A}$, and carotene were needed to raise the blood levels of the children in these mining communities to the "good" or "excellent" range. Since the 
hemoglobin concentrations of more than 40 per cent of the 7- to 9-year-old children were classified only as "fair," the need for more foods rich in iron for children in this age group is indicated.

Results of the dietary studies indicated that there was room for improvement in the diets of many of the children from each of the two schools studied. The diets of the children were relatively lower in calcium, phosphorus, riboflavin, and ascorbic acid than in other nutrients. However, many diets failed to meet the recommendations set up by the National Research Council for all nutrients.

In many cases, a number of children were consuming foods which supplied less than one-half of the NRC daily allowances. A greater proportion of the 7- to 9-year-old children had diets which met or exceeded the recommendations for all nutrients, while a larger number of the 13- to 15-year-old students had diets which failed to meet these recommendations. In this older age group the boys had better diets than the girls, except for intakes of niacin and ascorbic acid.

Although in most cases only a small percentage of the children examined showed signs of those physical conditions which may be evidence of poor nutrition, it should be emphasized that dietary deficiencies may exist for long periods before any physical signs of nutritional deficiencies appear. The medical inspections, therefore, tended to substantiate the results of the blood and dietary studies, since more than 35 per cent of the children exhibited mild cases of cheilosis and gingivitis, which are sometimes attributed to a deficiency of riboflavin, niacin, iron, or ascorbic acid.

\section{SUMMARY}

A study of the nutritional status of 462 grade school and junior high school students from four mining communities in Monongalia County, West Virginia, was made at West Virginia University during the school year of 1952-53. Dietary studies, microchemical blood studies, and medical inspections were used in an attempt to evaluate nutritional status.

Results of the blood analyses indicated that many children had low blood levels of vitamin A, carotene, and ascorbic acid. Information concerning dietary intake at two schools indicated that many diets were low in calcium, phosphorus, riboflavin, and ascorbic acid. Although medical inspections of these school children revealed comparatively few signs of deficiencies generally related to poor diets, a number of the boys and girls had mild cases of gingivitis and cheilosis. Such conditions often are attributed to deficiencies of riboflavin, niacin, iron, or ascorbic acid. Some enlargement of the thyroid gland, generally related to a lack of iodine, also was noted. 
Most diets could have been raised to meet the NRC Recommended Dietary Allowances by the addition of more citrus fruits, green and yellow vegetables, milk, milk products, and whole grain cereals. Due to the incidence of simple goiter in several age groups, the use of iodized salt should be encouraged in these mining areas.

\section{MINING FAMILIES IN MONONGALIA COUNTY}

Work, described in the preceding sections, with school children from four small mining communities in Monongalia County, West Virginia, indicated that certain nutritional deficiencies may exist. The families of those children who were found to be in poor nutritional condition were asked to participate in additional nutrition studies. Thirty-nine families agreed to cooperate in this work.

In the summer of 1953, these families were asked to assemble at central meeting places. At that time microchemical blood analyses and medical inspections of all parents and children present were made. This study included 17 men and 40 wo:nen ranging from 21 to 70 years of age, as well as 72 boys and 65 girls between the ages of 1 and 18. Table 11 shows the number of persons in each age group. All of the mothers and most of the children cooperated in this work. Due to conflicting work schedules, employment away from home, physical disability, or lack of interest, it was impossible to obtain data from many of the fathers.

\section{Living Conditions}

All families included in the study were living in small mining communities. About 44 per cent owned their homes, and 56 per cent lived in rented houses. The number of rooms per house varied from one to eight, with the average being five. All houses were wired for electricity and 80 per cent had running water. Very few homes, however, had sanitary conveniences.

\section{EMPLOYMENT}

Almost 64 per cent of the men in the families were employed by mining companies, 21 per cent were unemployed due to physical disability, 12 per cent were employed by non-mining concerns, and 3 per cent were farmers. Although 15 per cent of the women studied were either widowed or divorced, none was employed outside the home.

\section{Educational Background}

Approximately 3 per cent of the adults studied had no formal education, and 36 per cent had withdrawn from school before reaching the seventh grade. Less than 5 per cent had gone beyond the tenth grade. 


\section{RESULTS}

\section{BLOOD LEVELS}

The data collected have been grouped in Table 12 according to the rating scale devised by O. A. Bessey and O. H. Lowry (17). (See Table 2.)

The hemoglobin ratings for most of the subjects were either "fair" or "good." The 1-3-year age group and adult males were exceptions and were predominantly in the "poor" and "excellent" groups respectively.

More than half of the children were rated "poor" or "fair" for blood serum levels of ascorbic acid, vitamin A, and carotene. This is not surprising because many of the children in this study were selected on the basis of having been found to have low serum levels of one or more of these constituents. The parents, too, had low serum ascorbic acid levels-more than 70 per cent of them were rated either "poor" or "fair." However, the parents had higher levels of vitamin A than the children-more than 70 per cent were in the "good" or "excellent" range. Most of the parents were rated either "fair" or "good" for carotene.

\section{MEDICAL INSPECTIONS}

Some physical signs possibly related to nutritional deficiencies were found in a large portion of the adult group. (See Table 13.) Thickening of the bulbar conjunctiva was observed in 18 per cent of the men. Cheilosis was seen in 18 per. cent of the men and 10 per cent of the women.

Numerous gum signs were observed. Swelling, thickening, recession, and retraction of the gums and blunting of the interdental papilla were all observed in a relatively high percentage of the adults, as shown in Table 13.

The incidence of the above gum signs was appreciably lower in the children than in the parents in spite of the fact that more than onefourth of the parents were toothless and consequently could not exhibit the signs. However, this is to be expected since extended periods of dietary deficiency are usually required to produce physical signs of malnutrition.

Nasolabial seborrhea was common in teen-age boys but not in other groups.

The possible nutritional significance of the presence of most of the signs listed in Table 13 is discussed on page 13.

\section{Height AND Weight}

Table 14 shows the distribution of subjects according to weight classification. It is noteworthy that 60 per cent of the women were 10 per cent or more above normal (average for their height and weight), 
whereas 28 per cent were 10 per cent or more below normal. A smaller portion of the men than women were overweight and a larger portion were underweight. Perhaps this is to be expected in men doing hard physical labor under conditions unfavorable to maintaining good dietary habits.

The children also tended to be underweight more frequently than overweight. This might be expected in view of the fact that blood nutrient levels and a fairly high incidence of physical signs both indicate that these children were undernourished. A limited number of diet records on individuals in this group also tend to indicate that these children are undernourished.

\section{Nutritional Status in Terms of Family Groups}

To study the variation in blood levels which might occur within each family group, the results of the microchemical blood analyses have been presented in Table 15 in terms of individual family units. Persons from the same family tended to have similar carotene ratings. Such tendencies were also noted for hemoglobin, vitamin A, and, to a lesser extent, ascorbic acid.

As might be expected, more physical signs possibly related to nutritional deficiencies were observed in the older age groups. Therefore, no attempt has been made to interpret the results of the medical inspections in terms of family units. It should be noted, however, that in many cases several persons in the same family showed similar signs of nutritional deficiencies.

\section{DISCUSSION}

Results of the blood determinations for hemoglobin, ascorbic acid, vitamin $\mathrm{A}$, and carotene indicated than many subjects had low blood levels for these nutrients. Since the families included in this study were selected on the basis of nutritional deficiencies detected in school children during the 1952-53 school year, it is not surprising that, in all age groups, at least 50 per cent of the children were rated as "poor" or "fair" for hemoglobin, ascorbic acid, vitamin A, and carotene.

In the adult group studied, 18 per cent of the men and 38 per cent of the women were rated as "poor" or "fair" for hemoglobin. For vitamin A, only 18 per cent of the men and 32 per cent of the women fell in these low ranges, although 65 per cent of the men and 71 per cent of the women were rated as "poor" or "fair" for carotene. In comparison, almost 92 per cent of the men and 74 per cent of the women received these low ratings for ascorbic acid.

Medical inspections of the children from one to 12 years of age revealed few physical signs of nutritional deficiencies, although 11 per 
cent of the children in this age range had mild cases of cheilosis which may have been caused by a deficiency of riboflavin, niacin, or iron. Twenty-five per cent also showed some abnormality of the gums, which might be attributed to a deficiency of ascorbic acid. The incidence of physical signs was higher for the teen-age students. Twenty-three per cent of the boys and 13 per cent of the girls had cheilosis, while various changes in the gums were noted for a majority of both boys and girls. Nasolabial seborrhea, which might have been caused by a deficiency of riboflavin, vitamin $\mathrm{A}$, or ascorbic acid, was noted for 36 per cent of the boys and 6 per cent of the girls.

For the adults, more physical signs were noted. Eighteen per cent of the men and 8 per cent of the women showed thickening of the bulbar conjunctiva which may have been related to a deficiency of vitamin A. Eighteen per cent of the men and 10 per cent of the women also had mild cases of cheilosis. A number of gum conditions were observed in this group, with the incidence of specific signs ranging from 6 to 53 per cent for the men and 3 to 30 per cent for the women.

\section{SUMMARY}

During the summer of 1953, a study was made of the nutritional status of 39 families living in small mining communities in Monongalia County, West Virginia. Previous nutrition studies conducted in this area had indicated that many school children had poor dietary habits and low blood values for ascorbic acid, vitamin $\mathrm{A}$, and carotene. The subjects of this study were selected on the basis of this work and included the families of those children believed to be in poor nutritional condition.

The results of the microchemical blood analyses and medical inspections made for these family members indicated that dietary deficiencies of ascorbic acid, vitamin A, riboflavin, and iron existed. When the results of the blood analyses were examined in terms of individual family units, there was a tendency for members of a family to receive the same rating.

\section{General Discussion of Results}

Except for thiamine, riboflavin, and niacin, which most children were ingesting in adequate amounts, the nutrient intakes for the West Virginia boys and girls seemed comparable to those reported by other workers. For the children from 7 to 12 years of age, the diets contained a smaller proportion of the NRC allowances for calcium, phosphorus, and ascorbic acid than for any other nutrient. Clayton (9) found that the greatest deficiencies in the diets of the Maine children were in ascorbic acid, thiamine, riboflavin, niacin and calcium (this 
study was made before the Maine flour enrichment bill was passed). Potgieter (11) reported that almost 10 per cent of the children studied in Connecticut were eating no foods rich in ascorbic acid.

In contrast to the results of the West Virginia study, Young et al. (10) reported that children from 4 to 12 years of age in New York state had diets which were adequate when evaluated in terms of the NRG recommendations. The caloric intake of the 10- to 12-year-old children, however, failed to meet this standard.

For the teen-age students included in the West Virginia studies, diets were less adequate for calcium, phosphorus, riboflavin, and ascorbic acid than for any other nutrients. Except for ascorbic acid and niacin intakes, the boys had better diets than the girls. Tucker et al. (2) reported that, for the teen-age students studied at Maine, New York, and Rhode Island, the boys had higher intakes of all nutrients than the girls. The highest percentage of subjects were below the NRC recommendations for calcium, ascorbic acid, and vitamin A.

Results of the blood analyses for the third and fourth grade school children and for the children from mining areas in Monongalia County indicated that many subjects had low blood levels of vitamin A, carotene, and ascorbic acid. In addition, hemoglobin values tended to be low for the children in the 10- to 12- year age group, since almost 65 per cent of these boys and girls ranked in the "poor" or "fair" range for hemoglobin. Only 25 per cent of the teen-age boys and 15 per cent of the teen-age girls received these low ratings.

These homoglobin values were lower than those reported by Clayton et al. (3), where approximately 43 per cent of the 10- to 12-year-old children in New York state had hemoglobin concentrations which would fall in the "poor" or "fair" range, whereas less than 10 per cent of the 13- to 15-year-old children studied in Maine, New York, and Rhode Island were rated as "poor" or "fair" for hemoglobin.

The proportion of West Virginia children under 13 years of age rated as "poor" or "fair" for serum ascorbic acid ranged from 38 to 52 per cent. About 69 per cent of the 13- to 15-year-old children received these low ratings. In contrast, Clayton et al. (3) reported only 15 per cent of the children under 13 years of age with ascorbic acid values which would fall in the "poor" or "fair" range. In the 13- to 15-year age group, however, 52 per cent of the boys and 35 per cent of the girls were rated only as "poor" or "fair" for ascorbic acid.

In the 7- to 12-year age group studied at West Virginia, almost 65 per cent of the children were rated as "poor" or "fair" for serum vitamin A. Almost 55 per cent of the teen-age students also received these low ratings. Similar serum levels of vitamin A were reported by Clayton et al. (3) for less than 25 per cent of the children under 13 years 
of age and for 40 per cent of the boys and girls in the 13- to 15-year age group.

In West Virginia, serum carotene values were comparatively low. The proportion of children in the 7- to 12-year age group rated as "poor" or "fair" for this nutrient ranged from 65 to 85 per cent. Sixtyeight per cent of the teen-age boys and 74 per cent of the teen-age girls also received these low ratings. Clayton et al. (3) reported serum carotene values which would fall in the "poor" or "fair" range for only 32 per cent of the children under 13 and for about 60 per cent of the children in the 13- to 15-year age group.

Medical inspections of children in West Virginia revealed relatively few physical signs of severe nutritional deficiencies. However, these medical findings tended to substantiate the results of the dietary and blood studies, since certain mouth and gum conditions sometimes attributed to deficiencies of riboflavin, niacin, iron, and ascorbic acid were observed in almost all age groups.

Mild cases of cheilosis were noted for about 17 per cent of the third and fourth grade school children and for 43 per cent of the children from 7 to 12 years of age living in mining communities. Cheilosis also was reported for 42 per cent of the teen-age boys and 16 per cent of the teenage girls. Mild cases of gingivitis were observed in about 35 per cent of the children in the 7- to 12-year age group, whereas 54 per cent of the boys and 34 per cent of the girls from 13 to 15 years of age showed similar gum conditions.

Babcock et al. (4) reported that only 3 per cent of the children under 13 years of age studied in New York state showed signs of cheilosis, and less than 1 per cent of the children in this age group had mild cases of gingivitis. Less than 5 per cent of the 13- to 15-year-old subjects showed signs of cheilosis, and less than 1 per cent showed signs of gingivitis. On the other hand, medical inspections of children from 13 to 15 years old in Maine (4) revealed that about 30 per cent had mild cases of cheilosis and that almost 25 per cent showed signs of gingivitis.

It should be noted that slight enlargement of the thyroid gland was observed for about 12 per cent of the children studied in West Virginia. In contrast, Babcock et al. (4) reported similar enlargement for 1 per cent of the children studied in Maine and for only 5 per cent of the children studied in New York. This higher incidence of simple goiter among West Virginia school children indicates the need for more widespread use of iodized salt.

Dietary studies, microchemical blood analyses, and medical inspections of grade school and junior high school students in Monongalia County, West Virginia, indicated that children living in small mining 
or industrial communities had poorer diets than did those living in urban areas around Morgantown, West Virginia. Differences in dietary patterns probably would have been more pronounced were it not for the school lunch programs in many of the industrial areas. These findings corroborate the work of Mack et al. (7) who reported that the children from a college community in Pennsylvania were in better nutritional condition than were those from an industrial city.

Blood studies and medical inspections of parents and children from 39 families living in mining areas suggest that inadequate dietary intakes of ascorbic acid, vitamin A, and carotenes might be common, not only to school children but to all family members. Because the diets of the children were more frequently deficient in calcium, phosphorus, vitamin A, ascorbic acid, and riboflavin than in other nutrients, it is recommended that use of more milk, green and yellow vegetables, citrus fruits, whole grain cereals, and iodized salt be emphasized in West Virginia. 
1. Northeast Regional Publication No. 5. Cooperative Nutritional Status Studies in the Northeast Region: I. Techniques. Cornell Univ. Agr. Exp. Sta. Mem. 307, 1951.

2. Tucker, Ruth E., and others, Cooperative Nutritional Status Studies in the Nortieast Region: IV. Dietary Findings. R. I. Agr. Exp. Sta. Bull. 319, Contr. 802, 1952.

3. Clayton, Mary M., and others, Cooperative Nutritional Status Studies in the Northeast Region: $V$ Blood Findings. Maine Agr. Exp. Sta. Bull. 516, 1953.

4. Babcock, M. J., and others, Cooperative Nutritional Status Studies in the Northeast Region: II. Physical Findings. N. J. Agr. Exp. Sta. Bull. 763, 1952.

5. Pierce, Harold B., and others, "Nutritional Defects Among Children in Vermont." N. Eng. J. Med., 233:612-17 (1945)

6. Zayaz, Stella L., and others, "Nutritional Status of School Children in a Small Industrial City." Child Dev., 11:1-25 (1940).

7. Mack, Pauline B., and others, "Mass Studies in Human Nutrition: Nutritional Status of Children in a College Communiťy." J. Amer. Diet. Assn., 18:69-78 (1942).

8. Best, Mabel F., "West Virginia Food Study." J. Home Econ., 38:3-12 (1946).

9. Clayton, Mary M., Four-year Study of the Food Habits and Physical Condition of Grade School Children in Newport, Maine. Maine Agr. Exp. Sta. Bull. 430, 1944.

10. Young, Charlotte M., Smudski, Vivian L., and Steele, Betty F., "Fall and Spring Diets of School Children in New York State." J. Amer. Diet. Assn., 27:289-292 (1951).

11. Potgieter, Martha, and Everitt, Viola, "A Study of Children's Eating Habits." J. Home Econ., 42:363-66 (1950).

12. Boyd, Ed. French, Eads, Mariam G., and Sanstead, Harold R., Food Value Tables for Calculation of Diet Records. U.S. Pub. Health Ser. Fed. Sec. Agen. 1947.

13. Bureau of Human Nutrition and Home Economics. Composition of Foods, Raw, Processed, Prepared. U.S.D.A. Agr. Hdb. No. 8, 1950.

14. Babcock, M. J., Simplification of the "Long-Method" for Calculating the Nutritional Value of Diets. N.J. Agr. Exp. Sta. Bull. 751, 1950.

15. Chalmers, Faith W., and others, "The Diat Record-How Many and Which Days." J. Amer. Diet. Assn., 28:711-717 (1952).

16. National Research Council Reprint and Circular Series. No. $129 . \quad$ Recommended Dietary Allowances. Nat. Res. Council, 1948.

17. Bessey, O. A., and Lowry, O. H., Nutritional Assay of 1,200 New York State School Children. Meals for Millions. Final Rept., N.Y. Joint Legislative Comm. on Nutrition, pp. 167-192 (1947).

18. Jolliffe, N., Tisdall, F., and Cannon, P., (editors), Clinical Nutrition. New York, Paul B. Hoeber, Inc. 1950.

19. Cayer, David, "Recognition and Treatment of Early Vitamin Deficiency States." J. Amer. Med. Assn., 132:558 (1946).

20. Babcock, M. J., and others, Cooperative Nutritional Status Studies in the Northeast Region: VI. Correlations. W.Va. Univ. Agr. Exp. Sta. Bull. 361T, 1953

21. Baldwin, B. F., and Wood, T. D., "Weight-Height-Age Table for Children of School Age." Rose's Foundations of Nutrition, Edit. No. 4, New York, MacMillan, 1944.

22. Davenport, C. B., Carnegie Inst., Wash., Pub. 329, 1923. 
Table 1. Comparison of Nutrient intake with Respect to the National Research Council Recommended Daily Allowances* (Third and Fourtir Grade Children)

\begin{tabular}{|c|c|c|c|c|}
\hline \multirow{2}{*}{ NUTRIENTS } & \multicolumn{4}{|c|}{ Percentage of NRC allowances } \\
\hline & $100 \%$ OR MORE & $67 \%-99 \%$ & $50 \%-66 \%$ & $49 \%$ OR LESS \\
\hline Calories ............... & 47.0 & 46.0 & 5.6 & 1.4 \\
\hline Protein ................. & 64.0 & 31.9 & 3.2 & .9 \\
\hline Calcium ................. & 56.0 & 25.3 & 9.1 & 9.6 \\
\hline Phosphorus ........ & 33.3 & 47.9 & 13.2 & 5.6 \\
\hline Iron & 60.0 & 37.7 & 2.1 & .2 \\
\hline Thiamine ............. & 68.6 & 28.0 & 3.2 & .2 \\
\hline Riboflavin ........... & 68.8 & 21.4 & 5.6 & 4.2 \\
\hline Niacin ................ & 46.5 & 44.0 & 8.8 & .7 \\
\hline Ascorbic Acid $\quad . .$. & 35.3 & 29.1 & 16.3 & 19.3 \\
\hline
\end{tabular}

*Each figure represents percentage of subjects. (No. of subjects $=430$.)

Table 2. Key to Interpretation of Blood Levels in Terms of ADEQUACY OF Nutrition*

NUTRIENT IN BLOOD

Vitamin A ( $\mu \mathrm{g} . / 100 \mathrm{ml}$. Carotene $(\mu \mathrm{g} . / 100 \mathrm{ml}$. Ascorbic Acid (mgs. $/ 100 \mathrm{ml}$.) Hemoglobin (gms./100 ml.)

Females, all ages

Males, under 13

Males, 13 \& 14

Males, over 14

\begin{tabular}{|c|c|c|c|}
\hline \multicolumn{4}{|c|}{ INDICATED LEVEL OF NUTRITION } \\
\hline POOR & FAIR & GOOD & EXCELLENT \\
\hline BeIow 20 & $20-29$ & $30-49$ & $50 \&$ above \\
\hline Below 75 & $75-124$ & $125-199$ & $200 \&$ above \\
\hline Below 0.4 & $0.4-0.6$ & $0.7-1.0$ & $1.1 \&$ above \\
\hline Below 11.0 & $11.0-12.9$ & $13.0-13.9$ & $14.0 \&$ above \\
\hline Below 11.0 & $11.0-12.9$ & $13.0-13.9$ & $14.0 \&$ above \\
\hline Below 11.5 & $11.5-13.4$ & $13.5-14.4$ & $14.5 \&$ above \\
\hline Below 12.0 & $12.0-13.9$ & $14.0-14.9$ & $15.0 \&$ above \\
\hline
\end{tabular}

*Bessey, O. A.. and Lowry, O. H., Nutritional Assay of 1,200 New York State School Children. Meals for Millions. Final Rept. N.Y. Joint Legislative Comm. on Nutrition, pp. 167-192 (1947).

Table 3. Percentage Distribution of Subjects According to Ratings of Blood Constituent Levels (Third and Fourth Grade Children)

\begin{tabular}{|c|c|c|c|c|c|}
\hline \multirow{2}{*}{$\begin{array}{l}\text { NUTRIENT } \\
\text { IN BLOOD }\end{array}$} & \multirow{2}{*}{$\begin{array}{c}\text { No. OF } \\
\text { SUBJECTS }\end{array}$} & \multicolumn{4}{|c|}{ INDICATED LFVEL OF NUTRITION* } \\
\hline & & Poor & FAIR & GoOD & EXCELLENT \\
\hline Hemoglobin & 339 & 3.6 & 58.7 & 27.7 & 10.0 \\
\hline Vitamin A .... & 231 & 23.8 & 40.3 & 32.0 & 3.9 \\
\hline Carotene .......... & 237 & 16.9 & 48.1 & 32.5 & 2.5 \\
\hline Ascorbic Acid & 365 & 9.0 & 29.0 & 20.0 & 42.0 \\
\hline
\end{tabular}

*Based on ratings suggested by Bessey \& Lowry as given in Table 2. 
Table 4. Percentage Incidence of Certain Physical Signs Possibly Related to Nutritional Deficiencies (Third and Fourth Grade CHILDREN)

\begin{tabular}{|c|c|c|c|c|}
\hline \multirow{2}{*}{ Phy sical Signg } & \multicolumn{3}{|c|}{ Percentage of SubJects* } & \multirow{2}{*}{$\begin{array}{c}\text { SUGGESTED DEFICIENCY } \\
(18,19,20)\end{array}$} \\
\hline & URBAN & INDUSTRIAL & $\begin{array}{c}\text { ALL } \\
\text { SUBJECTS }\end{array}$ & \\
\hline \multicolumn{5}{|l|}{ EYES } \\
\hline Blepharitis & 4.2 & 9.5 & 6.4 & Vitamin A, Riboflavin \\
\hline $\begin{array}{l}\text { Bulbar Conjunctiva, } \\
\text { increased yascularity }\end{array}$ & 10 & & & Ascorbic Acid Rihoflavin \\
\hline Bulbar Conjunctiva, & 1.0 & 0.3 & 3.4 & Ascorbic Acid, Ribonavin \\
\hline tbickening & 1.0 & 2.6 & 1.7 & Vitamin A, Riboflavin \\
\hline Outer Canthi, lesions ... & 2.6 & 7.4 & 4.7 & Riboflavin \\
\hline \multicolumn{5}{|l|}{ SKIN $\left(F_{A C E}\right)$} \\
\hline Nasolabial Seborrhea & .5 & & .2 & Riboflavin, Vitamin A or C \\
\hline Acne & .5 & & .2 & Riboflavin, Vitamin A \\
\hline \multicolumn{5}{|l|}{ Mouth } \\
\hline $\begin{array}{l}\text { Lips, cheilosis } \\
\text { Buccal Mucosa, }\end{array}$ & 22.0 & 11.6 & 16.5 & Riboflavin, Niacin, Iron \\
\hline stomatitis & & 1.0 & .5 & Niacin \\
\hline $\begin{array}{l}\text { Gingivitis } \\
\text { Tongue, }\end{array}$ & 19.4 & 19.6 & 19.4 & Ascorbic Acid \\
\hline $\begin{array}{l}\text { Tongue, } \\
\text { papillae changes .... }\end{array}$ & 1.6 & 1.1 & 1.7 & Riboflavin, Niacin \\
\hline \multicolumn{5}{|l|}{ THYroid GLAND } \\
\hline Enlargement & 12.6 & 10.6 & 11.8 & Iodine \\
\hline \multicolumn{5}{|l|}{ SKIN (ARMS) } \\
\hline Dermatitis & .5 & & .2 & \\
\hline Folliculosis & 4.7 & 2.6 & 3.7 & Vitamin A \\
\hline Purpura ...............-. & & .5 & .2 & Ascorbic Acid \\
\hline
\end{tabular}

*Total Number of Subjects Examined-406.

Table 5. Percentage of Subjects from Urban and Industrial Areas with Nutrient Intakes MeEting NRC DaIly Allowances (Third and Fourth Grade Children)

\begin{tabular}{l|c|c}
\hline \hline \multirow{2}{*}{ NUTRIENTS } & \multicolumn{2}{|c}{ PERCENTAGE OF SUBJECTS } \\
\cline { 2 - 3 } & $\begin{array}{c}\text { URBAN AREAS } \\
\text { N-205* }\end{array}$ & $\begin{array}{c}\text { INDUSTRIAL AREAS } \\
\text { N-198* }\end{array}$ \\
\hline Calories & 49.8 & 39.4 \\
Protein & 67.8 & 54.0 \\
Calcium & 63.4 & 46.0 \\
Phosphorus & 39.5 & 23.2 \\
Iron & 57.1 & 52.5 \\
Thiamine & 70.2 & 57.6 \\
Ribofiavin & 73.7 & 59.1 \\
Niacin & 52.7 & 38.4 \\
Ascorbic Acid & 40.5 & 26.3 \\
\hline
\end{tabular}

${ }^{*} \mathrm{~N}=$ number of subjects. 
Table 6. Percentage Distribution of Subjegts According to Ratings of Blood Constituent Levels (Third and Fourth Grade Children)

\begin{tabular}{|c|c|c|c|c|c|}
\hline \multirow{2}{*}{$\begin{array}{l}\text { NUTRIENT } \\
\text { IN BLOOD }\end{array}$} & \multirow{2}{*}{$\begin{array}{c}\text { No. OF } \\
\text { SUBJECTS }\end{array}$} & \multicolumn{4}{|c|}{ INDICATED LEVEL OF NUTRITION* } \\
\hline & & PoOr & FAIR & GOOD & EXCELLENT \\
\hline \multicolumn{6}{|l|}{ HEMOGLOBIN } \\
\hline Urban....... & 165 & 3.0 & 59.4 & 29.7 & 7.9 \\
\hline Industrial- & 151 & 4.6 & 59.6 & 26.5 & 9.3 \\
\hline \multicolumn{6}{|l|}{ VITAMIN A } \\
\hline Urban........ & 114 & 15.8 & 32.4 & 44.8 & 7.0 \\
\hline Industrial & 102 & 28.4 & 48.0 & 22.6 & 1.0 \\
\hline \multicolumn{6}{|l|}{ CAROTENE } \\
\hline Urban........ & 115 & 10.4 & 52.3 & 33.0 & 4.3 \\
\hline Industrial. & 107 & 20.6 & 45.7 & 32.8 & .9 \\
\hline \multicolumn{6}{|l|}{ ASCORBIC ACID } \\
\hline Urban.......... & 176 & 7.4 & 29.0 & 17.6 & 46.0 \\
\hline Industrial. & 167 & 10.8 & 29.3 & 23.4 & 36.5 \\
\hline
\end{tabular}

* Based on ratings suggested by Bessey \& Lowry as given in Table 2.

Table 7. Distribution of Subjects (Children from Mining Communities)

\begin{tabular}{|c|c|c|c|c|c|c|}
\hline \multirow{3}{*}{ AGE GROUP } & \multicolumn{4}{|c|}{ Number of SUbJECts } & \multirow{2}{*}{\multicolumn{2}{|c|}{ PHYSICAL EXAMINATIONS }} \\
\hline & \multicolumn{2}{|c|}{ DIETARY STUDIES } & \multicolumn{2}{|c|}{ BLOOD STUDIES } & & \\
\hline & Males & Females & Males & Females & Males & Females \\
\hline 7-9 & 28 & 48 & 71 & 80 & 70 & 79 \\
\hline $10-12$ & 51 & 46 & 99 & 77 & 96 & 74 \\
\hline $13-15 \quad \ldots \ldots \ldots$ & 32 & 36 & 62 & 73 & 58 & 68 \\
\hline TOTAL & 111 & 130 & 232 & 230 & 224 & 221 \\
\hline
\end{tabular}


Table 8. Percentage Distribution of Subjects According to Level of Nutrient Intake (Children from Mining Communities)

\begin{tabular}{|c|c|c|c|c|c|}
\hline \multirow[b]{2}{*}{ NUTRIENT } & \multirow[b]{2}{*}{ AGE GROUP } & \multicolumn{4}{|c|}{ Percentage of NRC allowance } \\
\hline & & $\begin{array}{c}100 \% \text { OR } \\
\text { MORE }\end{array}$ & $66.6-99.9 \%$ & $50-66.5 \%$ & $0.0-49.9 \%$ \\
\hline \multirow[t]{4}{*}{ Calories .. } & $7-9$ & 67.1 & 26.3 & 5.3 & 1.3 \\
\hline & $10-12$ & 25.8 & 56.7 & 14.4 & 3.1 \\
\hline & $13-15 \mathrm{M}$ & 21.9 & 46.9 & 21.9 & 9.3 \\
\hline & $13-15 \mathrm{~F}$ & 30.5 & 50.0 & 16.7 & 2.8 \\
\hline \multirow[t]{4}{*}{ Protein } & $7-9$ & 82.9 & 14.5 & 2.6 & 0.0 \\
\hline & $10-12$ & 50.5 & 41.2 & 7.2 & 1.1 \\
\hline & $13-15 \mathrm{M}$ & 43.7 & 34.4 & 18.8 & 3.1 \\
\hline & $13-15 \mathrm{~F}$ & 38.9 & 41.6 & 16.7 & 2.8 \\
\hline \multirow[t]{4}{*}{ Calcium } & $7-9$ & 73.7 & 10.5 & 9.2 & 6.6 \\
\hline & $10-12$ & 36.1 & 36.1 & 13.4 & 14.4 \\
\hline & $13-15 \mathrm{M}$ & 28.1 & 28.1 & 12.5 & 31.3 \\
\hline & $13-15 \mathrm{~F}$ & 19.4 & 30.6 & 27.8 & 22.2 \\
\hline \multirow[t]{4}{*}{ Phosphorus } & $7-9$ & 48.7 & 36.8 & 7.9 & 6.6 \\
\hline & $10-12$ & 13.4 & 48.5 & 24.7 & 13.4 \\
\hline & $13-15 \mathrm{M}$ & 9.4 & 37.5 & 21.9 & 31.2 \\
\hline & $13-15 \mathrm{~F}$ & 5.6 & 47.2 & 19.4 & 27.8 \\
\hline \multirow[t]{4}{*}{ Iron } & 7-9 & 76.3 & 18.4 & 5.3 & 0.0 \\
\hline & $10-12$ & 42.3 & 50.5 & 4.1 & 3.1 \\
\hline & $13-15 \mathrm{M}$ & 25.0 & 62.5 & 9.4 & 3.1 \\
\hline & $13-15 \mathrm{~F}$ & 13.9 & 58.3 & 25.0 & 2.8 \\
\hline \multirow[t]{4}{*}{ Thiamine } & $7-9$ & 84.2 & 14.5 & 1.3 & 0.0 \\
\hline & $10-12$ & 57.7 & 37.1 & 3.1 & 2.1 \\
\hline & $13-15 \mathrm{M}$ & 43.8 & 40.6 & 12.5 & 3.1 \\
\hline & $13-15 \mathrm{~F}$ & 38.8 & 50.0 & 5.6 & 5.6 \\
\hline \multirow[t]{4}{*}{ Riboflavin ....... } & $7-9$ & 82.9 & 11.8 & 4.0 & 1.3 \\
\hline & $10-12$ & 46.4 & 33.0 & 14.4 & 6.2 \\
\hline & $13-15 \mathrm{M}$ & 46.9 & 21.9 & 18.7 & 12.5 \\
\hline & $13-15 \mathrm{~F}$ & 38.8 & 50.0 & 5.6 & 5.6 \\
\hline \multirow[t]{4}{*}{ Niacin .. } & $7-9$ & 73.7 & 22.4 & 2.6 & 1.3 \\
\hline & $10-12$ & 50.5 & 41.3 & 7.2 & 1.0 \\
\hline & $13-15 \mathrm{M}$ & 34.3 & 53.1 & 6.3 & 6.3 \\
\hline & $13-15 \mathrm{~F}$ & 47.2 & 44.5 & 8.3 & 0.0 \\
\hline \multirow[t]{4}{*}{ Ascorble Acid } & $7-9$ & 65.8 & 19.7 & 7.9 & 6.6 \\
\hline & $10-12$ & 30.9 & 30.9 & 17.6 & 20.6 \\
\hline & $13-15 \mathrm{M}$ & 9.4 & 9.4 & 28.1 & 53.1 \\
\hline & $13-15 \mathrm{~F}$ & 16.7 & 27.8 & 19.4 & 36.1 \\
\hline
\end{tabular}


Table 9. Percentage Distribution of Subjects According to Ratings of Blood Constituent Levels (Children from Mining Communities)

\begin{tabular}{|c|c|c|c|c|c|}
\hline \multirow{2}{*}{ NUTRIENT } & \multirow{2}{*}{ RatiNG* } & \multicolumn{4}{|c|}{ AgE Grot:P } \\
\hline & & $7-9$ & $10-12$ & $13-15 \mathrm{MI}$ & $13-15 \mathrm{~F}$ \\
\hline \multirow[t]{4}{*}{ Hemoglobin } & Poor & 0.0 & 0.0 & 1.6 & 1.4 \\
\hline & Fair & 43.7 & 29.0 & 24.2 & 13.7 \\
\hline & Good & 38.4 & 36.9 & 29.0 & 37.0 \\
\hline & Excellent & 17.9 & 34.1 & 45.2 & 47.9 \\
\hline \multirow[t]{4}{*}{ Ascorbic Acid } & Poor & 26.4 & 19.3 & 46.6 & 40.0 \\
\hline & Fair & 19.4 & 28.9 & 22.3 & 28.6 \\
\hline & Good & 16.0 & 19.9 & 12.1 & 8.6 \\
\hline & Excellent & 38.2 & 31.9 & 19.0 & 22.8 \\
\hline \multirow[t]{4}{*}{ Vitamin A } & Poor & 34.0 & 39.1 & 35.4 & 20.6 \\
\hline & Fair & 30.8 & 30.8 & 27.4 & 31.8 \\
\hline & Good & 26.6 & 20.3 & 29.4 & 36.5 \\
\hline & Excellent & 8.6 & 9.8 & 7.8 & 11.1 \\
\hline \multirow[t]{4}{*}{ Carotene } & Poor & 14.9 & 23.9 & 14.3 & 20.0 \\
\hline & Fair & 50.0 & 47.2 & 43.6 & 53.8 \\
\hline & Good & 28.4 & 23.9 & 20.0 & 23.1 \\
\hline & Excellent & 6.7 & 5.0 & 7.3 & 3.1 \\
\hline
\end{tabular}

*Table 2 relates ratings to blood constituent levels.

Table 10. Percentage Incidence of Physical Signs Possibly Relaten to Nutritional Deficiencies*

(Children from Mining Communities)

\begin{tabular}{|c|c|c|c|c|}
\hline \multirow{2}{*}{ Physical Sign } & \multicolumn{4}{|c|}{ AgE GroUP } \\
\hline & $7-9$ & $10-12$ & $13-15 \mathrm{M}$ & $13-15 \mathrm{~F}^{*}$ \\
\hline \multicolumn{5}{|l|}{ EYES } \\
\hline Blepharitis & 12 & 11 & 9 & 12 \\
\hline $\begin{array}{l}\text { Bulbar Conjunctiva } \\
\text { increased vascularity }\end{array}$ & 3 & 2 & - & 一 \\
\hline \multicolumn{5}{|l|}{ SKIN (FACE) } \\
\hline $\begin{array}{l}\text { Nasolabial Seborrhea } \\
\text { Acne }\end{array}$ & - & $\stackrel{6}{-}$ & $\stackrel{29}{-}$ & $\begin{array}{r}27 \\
2\end{array}$ \\
\hline \multicolumn{5}{|l|}{ MovTH } \\
\hline Cheilosis & 43 & 43 & 41 & 16 \\
\hline Gingivitis & 30 & 35 & 53 & 34 \\
\hline Changes in Papillae ...... & 5 & 2 & - & 2 \\
\hline Fissuring of Tongue & 1 & 1 & - & - \\
\hline $\begin{array}{l}\text { THYROID GLAND } \\
\text { Enlargement (Goiter) }\end{array}$ & 7 & 11 & 2 & 13 \\
\hline SKIN (ARM) & & & & \\
\hline Xerosis & 1 & 1 & - & 2 \\
\hline Folliculosis & 7 & 11 & 9 & 4 \\
\hline
\end{tabular}

*See items 18, 19, 20 in list of references. 
Table 11. Distribution of Subjects by Ages (Mining Families)

\begin{tabular}{|c|c|c|c|c|c|c|c|c|c|c|}
\hline \multirow{4}{*}{ AGE RANGE } & \multicolumn{10}{|c|}{ NUMBER OF SUBJECTS } \\
\hline & \multirow{2}{*}{\multicolumn{2}{|c|}{$\begin{array}{l}\text { MEDICAL } \\
\text { INSP. }\end{array}$}} & \multicolumn{8}{|c|}{ BLOOD ANALySES } \\
\hline & & & \multicolumn{2}{|c|}{ HEMOGLOBIN } & \multicolumn{2}{|c|}{ AscORBIC ACID } & \multicolumn{2}{|c|}{ VITAMIN A } & \multicolumn{2}{|c|}{ CARotene } \\
\hline & $\mathrm{M}$ & $\mathbf{F}$ & $\mathrm{M}$ & $\mathbf{F}$ & M & $\mathrm{F}$ & $\mathrm{M}$ & $\mathrm{F}$ & $\mathrm{M}$ & $F$ \\
\hline \multicolumn{11}{|l|}{ Adults } \\
\hline $21-29$ & 1 & 5 & 1 & 5 & 0 & 4 & 1 & 5 & 1 & 5 \\
\hline $30-49$ & 12 & 31 & 12 & 31 & 9 & 21 & 12 & 30 & 12 & 30 \\
\hline \multirow[t]{2}{*}{$50 \&$ above } & 4 & 4 & 4 & 4 & 3 & 2 & 4 & 3 & 4 & 3 \\
\hline & - & - & - & - & - & - & - & - & - & - \\
\hline TOTAL & 17 & 40 & 17 & 40 & 12 & 27 & 17 & 38 & 17 & 38 \\
\hline \multicolumn{11}{|l|}{ Children } \\
\hline $1-3 \quad \ldots \ldots \ldots \ldots$ & 5 & 6 & 5 & 6 & 4 & 5 & 4 & 5 & 4 & 5 \\
\hline $4-6 \quad \ldots \ldots \ldots \ldots . . . . . . .4$. & 18 & 10 & 18 & 12 & 15 & 6 & 13 & 9 & 13 & 9 \\
\hline $7-9 \quad \ldots \ldots \ldots \ldots$ & 13 & 23 & 13 & 20 & 10 & 13 & 13 & 9 & 13 & 9 \\
\hline \multirow[t]{2}{*}{$10-12$} & 14 & 10 & 16 & 10 & 8 & 7 & 15 & 9 & 15 & 9 \\
\hline & $\overline{-0}$ & - & - & - & - & - & - & - & - & $\overline{20}$ \\
\hline TOTAL & 50 & 49 & 52 & 48 & 37 & 31 & 45 & 32 & 45 & 32 \\
\hline $13-15$ & 17 & 14 & 16 & 15 & 7 & 9 & 15 & 13 & 15 & 13 \\
\hline \multirow[t]{2}{*}{$16-18$} & 5 & 2 & 6 & 2 & 4 & 1 & 4 & 2 & 4 & 2 \\
\hline & - & - & - & - & - & - & - & - & - & - \\
\hline TOTAL & 22 & 16 & 22 & 17 & 11 & 10 & 19 & 15 & 19 & 15 \\
\hline
\end{tabular}

Table 12. Percentage Distribution of Subjects According to Ratings of Blood Constituent Levels* (Mining Families)

\begin{tabular}{|c|c|c|c|c|c|c|c|c|}
\hline \multirow{2}{*}{$\begin{array}{l}\text { NUTRIENT } \\
\text { IN BLOOD }\end{array}$} & \multicolumn{2}{|c|}{ ADULTS } & \multicolumn{6}{|c|}{$\begin{array}{l}\text { AGE GROUP } \\
\text { CHILDREN }\end{array}$} \\
\hline & MaLe & FEMALE & $1-3$ & $4-6$ & $7-9$ & $10-12$ & $|13-18 \mathrm{M}|$ & $13-18 \mathrm{~F}$ \\
\hline \multicolumn{9}{|l|}{ HEMOGLOBIN } \\
\hline Poor & 0 & 5 & 45 & 10 & 0 & 0 & 0 & 12 \\
\hline Fair & 18 & 33 & 36 & 77 & 61 & 39 & 50 & 53 \\
\hline Good ….............. & 29 & 30 & 18 & 10 & 33 & 58 & 27 & 24 \\
\hline Excellent ........ & 53 & 33 & 0 & 3 & 6 & 4 & 23 & 12 \\
\hline \multicolumn{9}{|l|}{ AsCORBIC ACID } \\
\hline Poor & 58 & 41 & 33 & 38 & 26 & 13 & 55 & 70 \\
\hline Fair ...................... & 33 & 33 & 11 & 19 & 26 & 33 & 9 & 10 \\
\hline Good .................. & 8 & 15 & 0 & 10 & 17 & 33 & 27 & 20 \\
\hline Excellent & 0 & 11 & 56 & 33 & 30 & 20 & 9 & 0 \\
\hline \multicolumn{9}{|l|}{ VItAMIN A } \\
\hline Poor & 18 & 18 & 22 & 55 & 44 & 33 & 26 & 27 \\
\hline Fair ….............. & 0 & 13 & 44 & 14 & 6 & 29 & 21 & 33 \\
\hline Good & 47 & 42 & 33 & 32 & 47 & 38 & 47 & 27 \\
\hline Excellent & 35 & 26 & 0 & 0 & 3 & 0 & 5 & 13 \\
\hline \multicolumn{9}{|l|}{ Carotene } \\
\hline Poor & 6 & 24 & 44 & 23 & 22 & 21 & 26 & 20 \\
\hline Fair ................... & 59 & 47 & 22 & 41 & 50 & 71 & 42 & 53 \\
\hline Good & 35 & 21 & 33 & 36 & 22 & 8 & 26 & 27 \\
\hline Excellent & 0 & 8 & 0 & 0 & 6 & 0 & 5 & 0 \\
\hline
\end{tabular}

*Tabie 2 relates ratings to blood constituent levels. 
Table 13. Percentage Incidence of Physical Signs* (Mining Families)

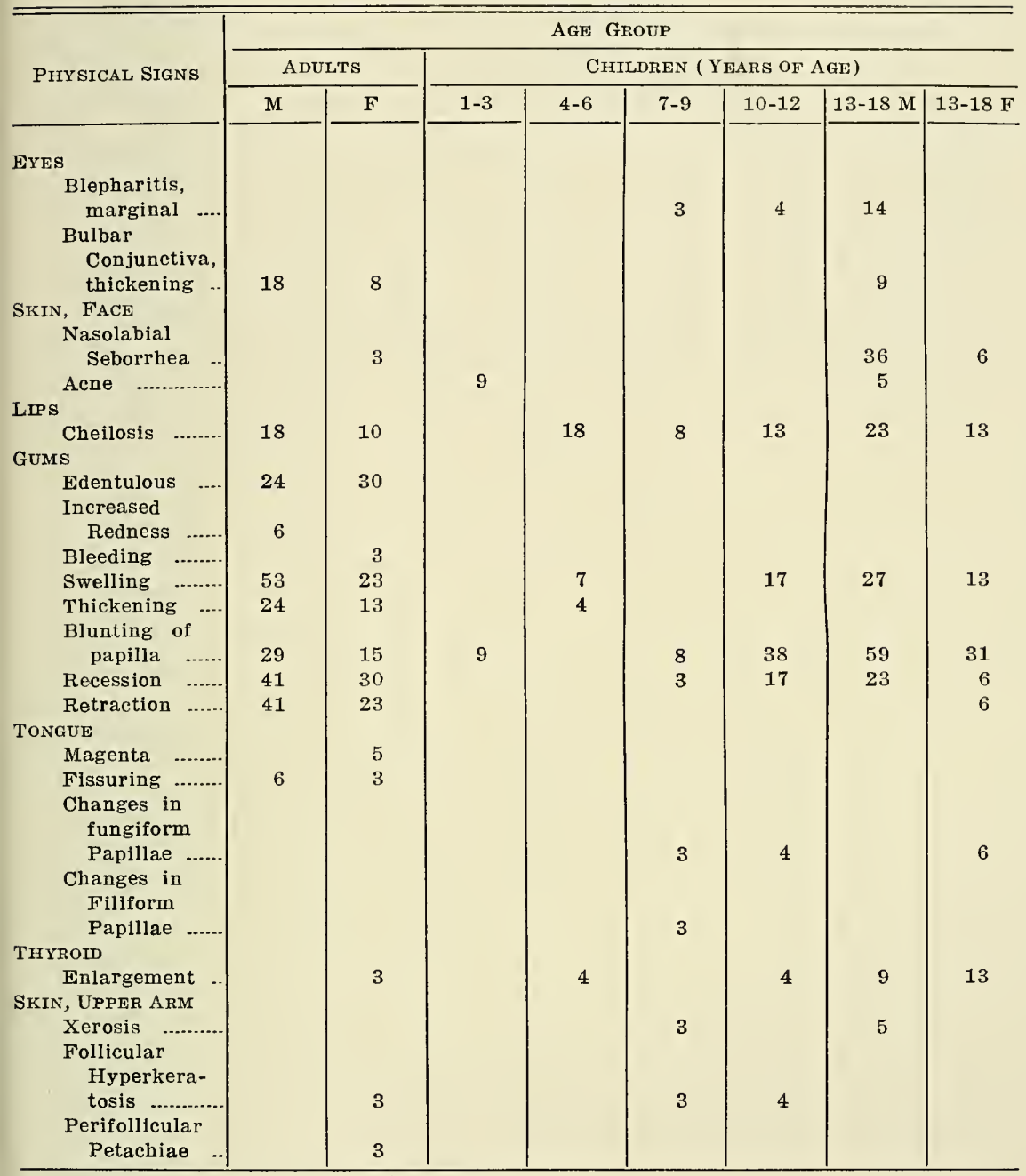

*See items 18, 19, 20 in list of references. 
Table 14. Percentage of Subjects in Each Weight Rating* (MINING FAMILIES)

\begin{tabular}{|c|c|c|c|c|c|}
\hline \multirow[b]{2}{*}{ SUBJECTs } & \multicolumn{2}{|c|}{ UNDERWEIGHT } & \multirow[b]{2}{*}{ NormaI } & \multicolumn{2}{|c|}{ OVERWEIGHT } \\
\hline & $\begin{array}{l}10 \% \text { or } \\
\text { MORE }\end{array}$ & $5 \%-9 \%$ & & $5 \%-9 \%$ & $\begin{array}{l}10 \% \text { oR } \\
\text { MORE }\end{array}$ \\
\hline ADULTS & & & & & \\
\hline Men & 17.6 & 41.2 & 17.6 & 0.0 & 23.6 \\
\hline Women & 27.5 & 2.5 & 5.0 & 5.0 & 60.0 \\
\hline CHILdREN & & & & & \\
\hline $\begin{array}{l}1 \text { to } 12 \text { years old } \\
13 \text { to } 18 \text { years old }\end{array}$ & 25.3 & 18.7 & 38.4 & 11.0 & 6.6 \\
\hline Boys ................... & 28.6 & 19.0 & 33.3 & 0.0 & 19.1 \\
\hline Girls & 58.8 & 11.8 & 17.6 & 5.9 & 5.9 \\
\hline
\end{tabular}

*Wreight ratings are based on the values given by Baldwin and Wood (21). 


